\title{
Depression and Psychological Well-Being among Living Institutionalized and Non- Institutionalized Elderly
}

\author{
Srisailamaiah. $\mathrm{M}^{1}$, Suresh. $\mathrm{K}^{2}$, Srikanth Reddy. $\mathrm{V}^{3}$
}

\section{ABSTRACT}

India is fast developing country. The elderly population is large and increasing due to development of health care facilities. Elderly people are facing physical, psychological and health issues due to economic impairment, urbanization, modernization. Globalizations have brought lifestyle changes which resulted in disintegration of joint family system and alternative living arrangements for elderly have come forward. Living in old age homes is becoming an option for elderly. This study is an attempt to find out the mean difference between depression and psychological well being among institutionalized and non- institutionalized elderly. To realize the objectives and to test the hypotheses formulated, two tools were used to assess depression and psychological wellbeing The Geriatric depression Inventory (Holroyd \& Clayton, 2000), and Psychological Wellbeing Scale (Bhogley \& Prakash, 1995), were used on elderly population. For purposes of the present study, a total sample of 60 were taken out of which 30 were ( $60+$ years ) elderly people from old age homes and 30 were $(60+y$ ears) from noninstitutionalized elderly from Tirupati in Chittoor district, Andhra Pradesh. ' $t$ '-test was applied to check the difference of depression and psychological well being and the Karl-person ' $r$ ' method used to check the correlation. Result revealed significant differences in depression and psychological well being with respect to institutionalized and non- institutionalized elderly. While co-relation between depression and psychological well-being reveals -0.68 , negative correlation.

Keywords: Depression; Psychological Wellbeing; Institutionalized; Non- Institutionalized; Elderly People.

The process of human aging is complex and individualized which can occur in the biological, psychological and social sphere. Biological aging is characterized by progressive age-changes in

\footnotetext{
${ }^{1}$ Research Scholar, Department of Psychology, Sri Venkateswara University, Tirupati, Andhra Pradesh, India

${ }^{2}$ Research Scholar, Department of Psychology, Sri Venkateswara University, Tirupati, Andhra Pradesh, India

${ }^{3}$ Professor and Head, Department of Psychology, Sri Venkateswara University, Tirupati, Andhra Pradesh, India *Responding Author

(C) 2016 I M Srisailamaiah, K Suresh, S Reddy; licensee IJIP. This is an Open Access Research distributed under the terms of the Creative Commons Attribution License (http://creativecommons.org/licenses/by/2.0), which permits unrestricted use, distribution, and reproduction in any Medium, provided the original work is properly cited.
} 


\section{Depression and Psychological Well-Being among Living Institutionalized and Non- Institutionalized Elderly}

metabolism, chemical properties of cells, leading to impaired self-regulation, regeneration, structural changes in functional tissues and organs. The aging of humans is a physiological and dynamic process ongoing with time. In accordance with most gerontologists' assertions it starts in the fourth decade of life and leads to death. It is a natural and irreversible process which can run as successful aging, typical or pathological. Biological changes that occur with age in the human body affect mood, attitude to the environment, physical condition and social activity, and designate a separate place for seniors in the family and society (Dziechiaz and Filip 2014). Ageing refers to human awareness and its adaptability to the ageing process. Psychical ageing refers to human awareness and his flexibility to the ageing process. Among adjustment attitudes we can make a distinction positive, dependence, hostile towards others and towards self attitudes. With progressed age, difficulties with adjustment to the new situation are increasing, adverse changes in the cognitive and intellectual sphere take place, perception process involutes, perceived ambiance and information received is lowered, and thinking processes change. Social ageing is limited to the role of an old person is culturally conditioned and may change as customs change. Social ageing refers to how a human being perceives the ageing process and how society, (Malgorzata, et.al.2014) .

The life expectancy of an average Indian has increased from 36.7 in 1951 to over 67.14 in 2012. Also the population of older adults (more than $60 \mathrm{yr}$ ) in India increased to 102 millions in 2011 Census of India (2011). Which shows males outnumbered females in India? The total elderly population in India (60 and above) increased from 24 million in 1961, to 43 million in 1981 It further increased to 57 million in 1991 and to 77 million in 2001 and is expected to rise to 301million in 2051 and 340million in 2061 (Liebig, 2003). Life expectancy of the aged population has also increased and females have higher life year's men among the elderly. Old age, the closing period in the life span people "move away" from previous. But due to natural and life style changes older people living in old aged homes have increased. The recent data shows that there are more than 1,000 old age homes in India with most of them located in the southern India. The old age homes are of two types: free and paid. The "free" type homes care for the destitute old people who have no family to support their care. They are given shelter, food, clothing and medical care. In the paid type, services are available for a price. These pay \& stay homes cater to the needs of elderly from middle income to higher income groups. A number of studies have discussed various reasons for the elderly to be in old age homes. Migration of children has been cited as a major reason for the elderly to move into old age homes. However, there are studies (Siva Raju, et 2011); which cite the need for independence as the reason why the elderly live in old age homes. Lack of care within the family, insufficient housing, economic hardship and break-up of joint family are also cited as reasons by many studies for older people to join in old age homes, (Bansod, \& Paswan, 2006; Bharati, 2009; Mishra, 2008; Ramamurti \& Jamuna, 1996; Kalavar \& Jamuna, 2006). 


\section{Depression and Psychological Well-Being among Living Institutionalized and Non- Institutionalized Elderly}

Depression is becoming a very important issue in modern society. Depression is one of the most common psychological conditions during the normal course of life with so much of losses and disappointments. Depression itself refers to a heterogeneous set of phenomenon ranging from simple mood swings to severe affective state. With ensuing social problems to be expected, it may become the disease with the greatest social burden after ischemic heart disease. Considering that depression is the most common psychological problem in old age, its management in the elderly population is essential (Young Ju Jee, and Yun Bok Lee 2013). Geriatric depression is a major health hazard with devastating outcomes. According to Kalpan and Shadock (1999).15 to $20 \%$ of old population may experience depression in old age is quite complex. Introduces a "dual-channel” conception of well-being, which indicates that positive and negative dimensions of an individual's well-being are independent, as they are influenced by different variables. These findings are empirically endorsed in Smits, Deeg, and Bosscher's (1995) study of the associations of different facets of personal control with well-being among older adults. These authors found positive and negative affects to be associated with different control measures. Negative affect was associated with sense of coherence and neuroticism while positive affect was predicted by mastery with global well-being and social inadequacy (e.g., a feeling that a respondent cannot easily relate to others). All these studies point to the importance of assessing both positive and negative dimensions in psychological well-being research. Thus, in addition to happiness, this review Crawford \& Caltabiano (2011) focuses on depressive symptomatology as a construct connoting the aggregate of depressive symptoms including clinical depression.

In gerontology literature, the terms of psychological well-being and subjective well-being have been used interchangeably to represent identical concepts (Diener, 1984; George, 1981). In more recent literature, depending on the investigators' research framework, well-being terms present very similar or even identical constructs to successful aging (e.g., Iwamasa \& Iwasaki, 2011; Litwin, 2005; Rowe \& Kahn, 1998), quality of life (e.g., Lawton, 1999; Wiggins, Netuveli, Hyde, Higgs, \& Blane, 2008), health-related quality of life (e.g., Deck, 2002; Goulia, Voulgari, Tsifetaki, Drosos, \& Hyphantis, 2010), and life satisfaction (e.g., Gaymu \& Springer, 2010; Sparks, 2004).

Positive and negative dimensions influence an older adult's life course. Bradburn (1969) notes that the concept of psychological well-being can best be assessed as a function of two independent dimensions - positive and negative effect. This concept derives from data in Bradburn and Caplovitz's (1965) study of a probability sample of adults in four Illinois communities, although the details of this study were not described. Against this background, the aim of the study was to find out the mean difference between depression and psychological well being among elderly people who are living in old-age homes and living in the community along with their families. Depression is common in the elderly and is a major public health problem. The World Health Organization, (2005) also emphasizes that depression, which is the fourth 


\section{Depression and Psychological Well-Being among Living Institutionalized and Non- Institutionalized Elderly}

most common illness, can lead to physical, emotional, social and economic problems .The prevalence rate of depression varies worldwide and their prevalence rates range between $10 \%$ and 55\% (Sherina, Rampal, and Mustaqim, 2004., Khattri, and Nepal, 2006).Study shows the depression ranges from $34.6 \%$ to $77.5 \%$ in old age home. (Weyerer, Mann, and Ames, 1995).Depression in late life is associated with significant morbidity, including deficits in a range of cognitive functions and considerable influence on functional impairment, disability, decreased quality of life, and has a negative effect on the body's recovery from illness, increases the rate of suicide, increases use of health care services and expenses and can result in early death and disturbance in the general state of wellness. (Kaplan and Shadock 1996, Mathur and Sen 1989).

Chalise (2014), A study was conducted in 2014 indicates that many elderly living in the Briddashrm are suffering from depression. Finding indicates that the prevalence of depression was $57.8 \%$. Among them $46.7 \%$ had mild, $8.9 \%$ had moderate and $2.2 \%$ had severe depression. There should be some interruption from the concerned authorities so that depression can be reduced which will support to the well-being and quality of life of elderly

\section{Objectives}

In the context of fore going observation a need was felt to analyzed the level of depression and psychological wellbeing among institutionalized and Non- institutionalized elderly with the following objectives .

1. To measure the levels of depression among institutionalized and non- institutionalized elderly.

2. To measure the state of psychological well being among institutionalized and noninstitutionalized elderly

3. To test co-relation between depression and psychological well being.

\section{Hypothesis}

Keeping the fore said objectives the following hypotheses were framed.

1. There would be significant differences in depression among institutionalized and noninstitutionalized elderly.

2. There would be significant differences in psychological well being among institutionalized and non- institutionalized elderly.

3. There would be co-relation between depression and psychological well being among elderly. 


\section{METHODOLOGY}

\section{Samples and Tools}

For purposes of the present study, a total sample of 60 were taken out of which 30 were (above 60 years) elderly people from old age homes and 30 were(above 60 years) from noninstitutionalized elderly people of Tirupati in Chittoor district ,Andhra Pradesh.

\section{Research Tools}

The following test tools were used. Their reliability, validity and objectivity mentioned in their respective manuals. Were taken as considered as criteria.

1. Geriatric Depression Inventory (GDS-15) reported to be the most suitable for screening depression in older adults (Holroyd \& Clayton, 2000). The GDS-15 has been translated to Telugu, the regional language and was administered to 30 older adults $(\mathrm{N}=30)$ with an internal of 10 days. The test-retest reliability of GDS-15 is 0.87 . The GDS-15 was standardized as part of ICMR funded project on Healthy Aging (Ramamurti, 1989).

2.Psychological Well Being Scale (Bhogley \& Prakash 1995) A 28 item scale as a quick measure of Psychological well-being is comprehensive, factor ally adequate, reliable and valid tool. The scale has internal consistency coefficient of 0.91 . Retest using the same questionnaire after three months, yielded a correlation of 0.72 . This scale has high correlation of 0.62 with subjective well-being questionnaire of Nagpal \& Sell (1985) and 0.48 with Subjective well-being questionnaire of Verma \& Verma (1989). Scoring: The 28 items on the scale have two response options: "yes" and "no". There is no right or wrong answers. If the response matches the scoring key, score of 1 is given. Maximum possible score is 28 with lower score indicative of low psychological well-being.

\section{Procedure}

The study was conducted on elderly male and female people who are staying in old age homes and staying at homes in the community along with their families. The entire process of fill the inventory was explained to them fully and clearly. The instructions given on the questionnaire were explained to them. It was also made clear to them that their scores would be kept secret. It was checked that none of the respondent left any questions unanswered.

\section{RESULTS AND DISCUSSION}

After collecting data from old age homes and non- institutionalized elderly people the scoring of the obtained data was done according to the manuals. Relevant statistical tests like " $t$ " test were applied and result tables were drawn. The interpretations of the results obtained are as follows.

Table 1: Showing the Mean, SD and "t" value of Depression

\begin{tabular}{|l|l|l|l|l|}
\hline & N & Mean & SD & T \\
\hline Institutionalized elderly people & 30 & 12.39 & 3.89 & \multirow{3}{*}{$3.65^{* *}$} \\
\hline Non- institutionalized elderly people & 30 & 10.21 & 3.01 & \\
\hline
\end{tabular}

(c) The International Journal of Indian Psychology, ISSN 2348-5396 (e)| ISSN: 2349-3429 (p) | 135 


\section{Depression and Psychological Well-Being among Living Institutionalized and Non- Institutionalized Elderly}

According to table 1 the results obtained on the basic area of depression reveals significant difference among adult and aged.

The Institutionalized elderly people mean score is12.39, the mean score of Non institutionalized elderly people is 10.21.with the standard deviation 3.89 and 3.01.respectively the $t$-value 3.65 is significant at 0.01 levels. Institutionalized elderly people are more depressive as compared with non- institutionalized elderly people. So we can say that first hypothesis there would be significant differences in depression among institutionalized and non- institutionalized elderly is not accepted.

Table 2: Showing the Mean, SD and " $t$ " value of Psychological wellbeing

\begin{tabular}{|l|l|l|l|l|}
\hline & N & Mean & SD & T \\
\hline Institutionalized elderly people & 30 & 128.60 & 10.11 & \multirow{3}{*}{$3.01^{* *}$} \\
\hline Non- institutionalized elderly people & 30 & 102.22 & 13.28 & \\
\cline { 1 - 5 }
\end{tabular}

According to table 2 the results obtained on the area of psychological well-being reveals that the mean of Institutionalized elderly people is 128.60 and the mean of non- Institutionalized elderly people is 102.22.Among the two groups the Institutionalized elderly mean is high indicating that psychological wellbeing is high in them then non- Institutionalized elderly then the second hypothesis there would be significant differences in psychological well being among institutionalized and non- institutionalized elderly " is accepted.

Table 2: Showing the correlation between depression and psychological Well-being

\begin{tabular}{|c|c|c|}
\hline Variables & N & r \\
\hline Depression & 30 & -0.68 \\
\hline Psychological Wellbeing & 30 & \\
\hline
\end{tabular}

According to table 3 the results shows that negative correlation between depression and psychological well-being. The -0.68 negative correlation between depression and psychological well-being. It means that as the depression increases the psychological well being decreases and when depression decreases the psychological well being increases, so that we can say there is a relationship between depression and psychological wellbeing. Then the hypothesis "There would be co-relation between depression and psychological well being among elderly" is accepted .The above results are in concordance with the earlier studies(Dhara and Jogsan 2013),which indicate that being away from family and the place of living creates a feeling of un-wantedness and results in a feeling of loneliness, which may lead to depression. The other significant finding of this study indicate that psychological wellbeing in higher among institutionalized elderly, this may be because of the better facilities and chance to share their feelings with other inmates which many create a feelings that they are not the one's who are in such and meaning are in similar situation . It might have made than that the cultural changes

(C) The International Journal of Indian Psychology, ISSN 2348-5396 (e)| ISSN: 2349-3429 (p) | 136 
have resulted because of lifestyle changes. India being a developing country, which is in a period of transition, such feelings are inevitable among institutionalized elderly people. It is pertinent at this junction to further probe the relation between psychological wellbeing and place of living because staying in a old age home for a long time might made the elder people to adjusted to the new life which improved the in psychological wellbeing.

\section{CONCLUSION}

There was a significant difference in depression and psychological well being among Institutionalized and non-Institutionalized elderly people, it shows that the depression increases the psychological well being decreases and depression decreases the psychological well being increases among the elderly people .There were -0.68 negative correlations are seen between depression and psychological well-being.

\section{Acknowledgments}

The author appreciates all those who participated in the study and helped to facilitate the research process.

\section{Conflict of Interests}

The author declared no conflict of interests.

\section{REFERENCES}

Aleksander \& Kobylarek. (2011).Aging Social, biological and psychological dimensions. Agencja Wydawnicza “Argi”, www.argi.pl,ISBN 978-83-60425-78-7.

Bansod. Dhananjay., \& Balram, Paswan.(2006). From Home to Old Age Home: A Situational Appraisal of Elderly in Old Age Home in Maharashtra. Help Age India: Research and Development Journal, 12 (3), 14-23.

Bharati, K. (2009). Old Age Homes: New Face of Old Age Care in India. Help age India Research and Development Journal, 15(2), 13-18.

Bradburn, N. M. (1969). The structure of psychological well-being. Chicago: Aldine Pub. Co.

Census of India. (2011). www.censusindia.net

Chalise, H. (2014). Depression among elderly living in Briddashram (old age homes). Advance in Aging Research, 12(3), 6-11.

Crawford, S. A., \& Caltabiano, N. J. (2011). Promoting emotional well-being through the use of humour. The Journal of Positive Psychology, 6(3), 237-252.

Deck, R., Kohlmann, T., \& Jordan, M. (2002). Health-related quality of life in old age: Preliminary report on the male perspective. Aging Male, 5(2), 87-97.

Dhara, RD., \& Jogsan, Y.A. (2013) Depression and Psychological Well-being in Old Age. Journal of Psychology and Psychotherapy, 3,117-122.

Diener, E. (1984). Subjective well-being. Psychological Bulletin, 95, 542-575. 


\section{Depression and Psychological Well-Being among Living Institutionalized and Non- Institutionalized}

Elderly

Dziechciaz,M.,\&Filip,R.(2014).Biological psychological and social determinants of old age: biopsycho-social aspects of human aging. Journal of Ageing and Society, 21(4), 835-838.

Gaymu, J., \& Springer, S. (2010). Living conditions and life satisfaction of older Europeans living alone: A gender and cross-country analysis. Ageing and Society, 30(7), 1153-1175.

George, L. K. (1981). Subjective well-being: Conceptual and methodological issues. In C. Eisdorfer (Ed.), Annual review of gerontology and geriatrics (pp. 345-382). New York: Springer.

Goulia, P., Voulgari, P., Tsifetaki, N., Drosos, A., \& Hyphantis, T. (2010). Comparison of health-related quality of life and associated psychological factors between younger and older patients with established rheumatic disorders. Aging and Mental Health, 14(7), 819-827.

Holroyd, S., \& Clayton, A. H. (2000). Measuring depression in the elderly: Which scale is best? Medscape General Medicine, 2(4), 430-554.

Iwamasa, G. Y., \& Iwasaki, M. (2011). A new multidimensional model of successful aging: Perceptions of Japanese American older adults. Journal of Cross-cultural Gerontology, 26(3), 261-278.

Joseph, S., \& Pullappally, T.J. (2010). A Study on the Psycho-Social Problems of Institutionalized Elderly with reference to Bhopal. BSSS Journal of social work, 2, 65-71.

Kalavar, J.M., \& Jamuna, D. (2006). Senior residents of 'Pay \& Stay' homes: An examination of health \& physical activity. Indian Journal of Gerontology, 20(1-2), 21-34.

Kaplan, H.I., \& Shadock, B.J. (1996). Concise Text book of clinical psychology. Lippiocott Williams and Wilkins, Philadelphia, USA.

Khattri, J.B., \& Nepal, M.K. (2006). Study of depression among geriatric population in Nepal. Nepal Medical College Journal, 8, 220-223.

Lawton, M. P. (1999). Quality of life in chronic illness. Gerontology, 45,181-183.

Litwin, H. (2005). Correlates of successful aging: Are they universal?. International Journal of Aging and Human Development, 61(4), 313-333.

Małgorzata Dziechciaż, Rafał Filip. (2014).Biological psychological and social determinants of old age: Bio-psycho-social aspects of human aging. Annals of Agricultural and Environmental Medicine, 21(4), 835-838.

Mathur, D., \& Sen, A. (1989). Depression in elderly and some of its psychological concomitants A study of efficacy of the age-care centre. Indian Journal of Community Guidance Service 16, 27-39.

Mishra, A.K. (2012).Are Elderly People Living In Old-Age Home, Less Depressed Than Those Of Immunity? Findings from a Comparative Study. Journal of Chitwan Medical College, 1(2), 5-8.

Nagpal, R., \& Sell, H. (1985) Subjective Well-Being. World Health Organization Regional Office for South East Asia, New Delhi, India. 
Ramamurti, P.V., \& Jamuna, D. (1996). Psychosocial aspects of elderly widows. In Vinodh Kumar (Ed.). Ageing: Indian Perspective and Global Scenario. New Delhi: Vinodh Kumar, 303-306.

Ramamurti, P.V., (1989). Psycho-Social Markers of Successful Ageing among Rural Elderly Men. In Pati, R.N and Jena,B. (Eds), Aged In India (Socio-Demographic Dimnsions). Ashish Publishing House. New Delhi

Rowe, J. W., \& Kahn, R. L. (1998). Successful aging. New York: Pantheon Books.

Sherina, M.S., Rampal, L. \& Mustaqim, A. (2004). The prevalence of depression among the elderly in Sepang, Selangor. Medical Journal of Malaysia, 59, 45-49.

Siva Raju, S., Giridhar, G., \& James, K.S. (2011). Studies on Ageing in India: A Review, BKPAI Working Paper No. 2, United Nations Population Citation Advice: Fund (UNFPA), New Delhi.

Smits, C. H. M., Deeg, D. J. H., \& Bosscher, R. J. (1995). Well-being and control in older persons: The prediction of well-being from control measures. International Journal of Aging and Human Development, 40(3), 237-251.

Sparks, M., Zehr, D., \& Painter, B. (2004). Predictors of life satisfaction: Perceptions of older community-dwelling adults. Journal of Gerontological Nursing, 30(8), 47-53.

Verma, S.K., \& Verma, A. (1989). Manual for PGI General Well-being Measure. Ankur Psychological Agency: Lucknow.

Weyerer, S., Mann, A.H. \& Ames, D. (1995) Prevalence of depression and dementia in residents of old age homes in Mannheim and Camden (London). Zeitschrift für Gerontology and Geriatric, 28, 169-178.

Wiggins, R. D., Netuveli, G., Hyde, M., Higgs, P., \& Blane, D. (2008). The evaluation of a selfenumerated scale of quality of life (CASP-19) in the context of research on ageing: A combination of exploratory and confirmatory approaches. Social Indicators Research, 89(1), 61-78.

World Health Organization. (2005). World Health Report.

Young Ju Jee,R.N., \& Yun Bok Lee,R.N.(2013). Factors Influencing Depression among Elderly Patients in Geriatric Hospitals, Journal of Physical Therapy Science,25(11),1445-1449.

How to cite this article: M Srisailamaiah, K Suresh, S Reddy (2016), Depression and Psychological Well-Being among Living Institutionalized and Non- Institutionalized Elderly, International Journal of Indian Psychology, Volume 3, Issue 4, No. 57, ISSN 2348-5396 (e), ISSN: 2349-3429 (p), DIP: 18.01.034/20160304, ISBN: 978-1-365-23993-9 